Biological and Clinical Sciences Research Journal

ISSN: 2708-2261

www.bcsrj.com

DOI: https://doi.org/10.54112/bcsrj.v2021i1.63

Biol. Clin. Sci. Res. J., Volume, 2021: 63

Original Research Article

\title{
ANTIOXIDANT ACTIVITY OF SYZYGIUM AROMATIUM AND CINNAMOMUM VERUM SEED EXTRACTS
}

\section{MAHMOOD H, ALI Q, *HAFEEZ MM, MALIK A}

\author{
Institute of Molecular Biology and Biotechnology, The University of Lahore, Lahore, Pakistan \\ Corresponding author: mansoorhafeez140@gmail.com
}

(Received, $20^{\text {th }}$ December 2020, Revised $28^{\text {th }}$ April 2021, Published $3^{\text {rd }}$ May 2021)

\begin{abstract}
The present study was carried out for the evaluation of antioxidant activities of clover (Syzygium aromatium L.) and cinnamon (Cinnamomum verum L.). The research work was carried out at the Institute of Molecular Biology, University of Lahore. The samples of clovers and cinnamon were collected from Lahore and were crushed to prepared sample in n-hexan, and ethanol extracts for evaluation of antioxidant activities. The highest antioxidant activities of ethanol extract from cinnamon indicated that the cinnamon may be used as an active ingredient to control stress conditions of cells for stress avoidance. The alkaloids, coumarins, saponins, flavonoids, tannins, sterols, quinons, triterpenoids, anthocyans, leucoanthocyans and terpenoids were tested for both ethanol and n-hexan extracts which indicated that most of the components were found present in both of the plant species, which revealed that these herbal plant seeds may be used as potential medicinal plants.
\end{abstract}

Keywords: clovers, cinnamon, antioxidant, ethanol, n-hexan

\section{Introduction}

As shown from the chemical diversity, the saponins have a very wide range for biological activities collectively. Many saponins have antioxidant, antibacterial and antiherbivore activity so these play a vital role in plant defense mechanism (Lo et al., 2004; Roby et al., 2013). The use of cinnamon (Cinnamomum verum L.) also showed antioxidant and antimicrobial activities against different bacterial strains including Bacteroides succinogenes, E. coli, Streptococcus bovis, Staphylococcus aureus, Ruminococcus flavefaciens and fungal strains including Penicillium roqueforti, Mucor plumbeus, Zygosaccharomyces rouxii, Candida lipolytica, Debaryomyces hansenii, Aspergillus flavus, Pediococcus halophilus and Pichia membranaefaciens. The use of cinnamon oil was carried out for the inhibition of microbial growth under control conditions. The cinnamon (Cinnamomum verum L.) largely produced by Indonesia up to $43 \%$ among all of the cinnamon producing countries while China contributes up to $33 \%$ in total world production of cinnamon (Diao et al., 2014; Zhang et al., 2016). The clovers (Syzygium aromatium L.) also an important plant which shows antioxidant and antimicrobial activities against bacterial strains like Clostridium E. coli, sticklandii, salmonella along with at some extant against fungal strains. The antioxidant and antimicrobial activities of clovers are due to the presence of soluble phenolics. The leaves of clovers are usually rich in with isoflavonoids, biochanin A and formioninetin (Anwar et al., 2009; Singh and Majumdar, 1999). The presence of pehnolic compounds showed the inhibitory activities against the growth and multiplication of microbes. The phenolic compounds in clovers also caused the fermentation of amino acids. The clover leaves and shoots may be used as antioxidants and antimicrobial medicines to prevent human, food and animals from attacks of microbes (Chesson et al., 1982; Dickinson et al., 1988; Lee et al., 2004). The chemical contents have been used for the formation of fungicidal lotions, antioxidant, pesticides and insecticides due to its insect repellent activities (Dua et al., 2013; Kaithwas et al., 2011; Singh et al., 2005). The sterols and aglycone triterpenes themselves encompass a wide range of structure with the nature of cyclization, oxidation in structure and variation in the degree. Secondly, variation with respect to sugar molecules and their numbers and nature of glycosylation, the presence of sugar chains and types of inter sugar chain linkages. Single sugar is attached at C-3 position in mono desmosidic saponins. While at $\mathrm{C}-28$ position in bidesmosidic saponins (like triterpenoid saponins), and in steroid saponins sugar are attached at C-26 position (Chesson and Forsberg 1997; Sullivan, 2009). The rumen bacterial strains caused disease in the intestine of animals which may lead towards the death of animal. These bacterial strains can be controlled or killed through the use of plant

[Citation: Mahmood, H., Ali, Q., Hafeez, M.M., Malik, A. (2021). Antioxidant activity of Syzygium aromatium and Cinnamomum verum seed extracts. Biol. Clin. Sci. Res. J., 2021: 63. doi: https://doi.org/10.54112/bcsrj.v2021i1.63] 
phytochemical or phenolic compounds as antimicrobial agents which are also used as potential antioxidants (Chesson et al., 1982; Stewart et al., 1997).

\section{Materials and methods}

The research was conducted in Microbiology Lab at the Institute of Molecular Biology and Biotechnology, The University of Lahore. The research work was done in the time period from November 2019 to March 2020. The seed samples were included Syzygium aromatium and Cinnamomum verum (Trifolium pretense L.) which was collected from market of Lahore, Pakistan.

\section{Preparation of plant extracts}

The dried samples were brought to the laboratory and crushed into small pieces by using laboratory grinder. After grinding for clovers (Syzygium aromatium and Cinnamomum verum (Trifolium pretense L.) were dipped in two different solvents ethanol and n-hexan ether depending on the amount required and kept for 2 weeks with vigorous shaking but the amount of samples was kept the different. All samples were taken in grams $(\mathrm{g})$ and solvents per milliliters ( $\mathrm{ml})$. After keeping the samples in the solvents for 2 weeks and samples were filtered using a whatman filter paper into a new bottle and then placed in the rotary evaporator. After the rotary process, samples were collected in falcon tubes and labeled accordingly and then placed in Petri plate for at least 1-2 days to evaporate completely. Dried extracts were collected and stored at refrigerator $4^{\circ} \mathrm{C}$ for further used detail shown in table below.

\section{Antioxidant activity}

Antioxidants are capable to inhibit or either delayed oxidation processes, which occurred under the effects of the atmospheric $\mathrm{O}_{2}$ or ROS (reactive oxygen species). They were used to stabilize polymeric products of foodstuffs, pharmaceuticals, petrochemicals and cosmetics. Antioxidants are involved in defense mechanism or immune system of organism against varieties of pathologies which are usually associated with the attacked of free oxygen radicals or ROS. To check the antioxidant properties of clovers (Syzygium aromatium L.) and cinnamon (Cinnamomum verum L.) plant DPPH assay was applied:

\section{2, 2-Diphenyl-1-picrylhydrazyl (DPPH) assay}

DPPH, known formally as 2, 2-dipheny1-1picrylhydrazl, was a cell-permeable, stable free radical that was commonly used to evaluate the ability of compounds to acted as free radical scavengers or hydrogen donors and to measure the antioxidant activity of flower, leaves, stem and roots extracts. The reaction of DPPH with an antioxidant or reducing compound produced the corresponding hydrazine DPPH, which could be followed by color changed from purple (absorbance at 515-528nm) to yellow (Adedayo et al., 2004). The antioxidant activity of the extracts was determined using the DPPH free radical scavenging assay described with some modifications. Briefly, the universal bottle was contained 501.1L of clovers (Trifolium pretense L.), Alsi (Linum usitatissimum L.), fennel or sonf (Foeniculum vulgare L.), cinnamon (Cinnamomum verum L.) extracts in concentrations from 1 to 5 $\mathrm{mg} / \mathrm{n} 11,0.004 \%$ (w/v) solution of DPPH was added. The obtained mixture was vortexed, incubated for 30 min in room temperature in a relatively dark place and then was read using spectrophotometer at 517 $\mathrm{nm}$. The blank was $80 \%$ (v/v) methanol. Ascorbic acid (vitamin C) was used for comparison. Measurements were taken in triplicate. DPPH scavenging effect was calculated using the following equation:

$$
\text { DPPH scavenging effect }(\%)=[(\mathrm{A} 0-\mathrm{A} 1) / \mathrm{A} 0) \times
$$

$$
\text { 100] }
$$

Where AO was the absorbance of negative control (0.004\% DPPH solution) and A was the absorbance in presence of extract. The results were reported as IC50 values and ascorbic acid equivalents (AAE, $\mathrm{mg} / \mathrm{g}$ ) of clovers (Syzygium aromatium L.) and cinnamon (Cinnamomum verum L.) extracts.

\section{Results and discussions}

The ethanol and n-hexan extracts from clover and cinnamon were used to find out the antioxidant activities present in the spices plants. The highest antioxidant activity (2.678) through ethanol plant extract at $50 \mu \mathrm{g} / \mathrm{ml}$ concentration was reported by cinnamon sample while lowest $(0.267)$ was recorded for clover. The highest antioxidant activity (0.568) through ethanol plant extract at $100 \mu \mathrm{g} / \mathrm{ml}$ concentration was reported by cinnamon sample while lowest (0.557) was recorded for clover. The highest antioxidant activity $(2.80,1.173,300)$ through ethanol plant extract at $200 \mu \mathrm{g} / \mathrm{ml}, 150 \mu \mathrm{g} / \mathrm{ml}$ and $250 \mu \mathrm{g} / \mathrm{ml}$ concentrations was reported by Cinnamon sample while lowest $(0.228,0.153,0.238)$ was recorded for clover respectively (Table 1 ). The lowest antioxidant activity (0.231) through n-hexan plant extract at $50 \mu \mathrm{g} / \mathrm{ml}$ concentration was reported by clover sample while higher $(0.275)$ was recorded for Cinnamon. The highest antioxidant activity (0.714) through n-hexan plant extract at $100 \mu \mathrm{g} / \mathrm{ml}$ concentration was reported by cinnamon sample while lowest (0.411) was recorded for clover. The highest antioxidant activity (1.241) through n-hexan plant extract at $150 \mu \mathrm{g} / \mathrm{ml}$ concentration was reported by cinnamon sample while lowest (0.171) was recorded for clover. The highest antioxidant activity (1.752) through $\mathrm{n}$-hexan plant extract at $250 \mu \mathrm{g} / \mathrm{ml}$ 
concentration was reported by cinnamon sample while lowest $(0.464)$ was recorded for clover. The highest antioxidant activity (0.565) through n-hexan plant extract at $200 \mu \mathrm{g} / \mathrm{ml}$ concentration was reported by cinnamon sample while lowest (0.232) was recorded for clover (Table 2). The alkaloids, coumarins, saponins, flavonoids, tannins, sterols, quinons, triterpenoids, anthocyans, leucoanthocyans and terpenoids were tested (Tables 3) for both ethanol and n-hexan extracts of clover and cinnamon which indicated that most of the components were found present in both of the species, which revealed that these herbal plants may be used as potential medicinal plants. The ethanol and n-hexan extracts from clovers and cinnamon were used to find out the antioxidant activities present in the spices plants. The highest antioxidant activities of ethanol extract from Cinnamon and clover indicated that the cinnamon and clover may be used as an active ingredient to control stress conditions of cells for stress avoidance. The highest antioxidant activities of ethanol extract from Cinnamon indicated that the cinnamon may be used as an active ingredient to control stress conditions of cells for stress avoidance. The highest antioxidant activities of ethanol extract from Cinnamon and clover indicated that the cinnamon and clover may be used as an active ingredient to control stress conditions of cells for stress avoidance (Anwar et al., 2009; Heng et al., 2006; Lee et al., 2004; Matan et al., 2006).

Table 1. Antioxidant activities of spices by ethanol extract

\begin{tabular}{|c|c|c|}
\hline Doses & clover (Syzygium aromatium $\mathbf{L})$. & Cinnamon (Cinnamomum verum L.) \\
\hline $50 \mu \mathrm{g} / \mathrm{ml}$ & 0.267 & 2.678 \\
\hline $100 \mu \mathrm{g} / \mathrm{ml}$ & 0.557 & 0.568 \\
\hline $150 \mu \mathrm{g} / \mathrm{ml}$ & 0.228 & 2.80 \\
\hline $200 \mu \mathrm{g} / \mathrm{ml}$ & 0.153 & 1.173 \\
\hline $250 \mu \mathrm{g} / \mathrm{ml}$ & 0.238 & 3.00 \\
\hline \multicolumn{3}{|c|}{ Table 2. Antioxidant activities of spices by n-hexan extract } \\
\hline Doses & clover (Syzygium aromatium L.) & Cinnamon (Cinnamomum verum L.) \\
\hline $50 \mu \mathrm{g} / \mathrm{ml}$ & 0.231 & 0.262 \\
\hline $100 \mu \mathrm{g} / \mathrm{ml}$ & 0.411 & 0.714 \\
\hline $150 \mu \mathrm{g} / \mathrm{ml}$ & 0.171 & 1.241 \\
\hline $200 \mu \mathrm{g} / \mathrm{ml}$ & 0.232 & 0.565 \\
\hline $250 \mu \mathrm{g} / \mathrm{ml}$ & 0.464 & 1.752 \\
\hline
\end{tabular}

Table 3. Phytochemical composition of clover (Syzygium aromatium $\mathbf{L}$.) and Cinnamon (Cinnamomum verum L.) seed extract

\begin{tabular}{lcr}
\hline Phytochemical & \multicolumn{2}{c}{ clover (Syzygium } \\
Ethanol extract & aromatium \\
n-hexan
\end{tabular}

Conclusions

The alkaloids, coumarins, saponins, flavonoids, tannins, sterols, quinons, triterpenoids, anthocyans, leucoanthocyans and terpenoids were tested for both ethanol and n-hexan extracts of clover (Syzygium aromatium L.) and Cinnamon (Cinnamomum verum L.) which indicated that most of the components were found present in both of the species, which revealed that these herbal plants may be used as potential medicinal plants. It was concluded that the Cinnamon (Cinnamomum verum L.) and clover (Syzygium
Cinnamon (Cinnamomum verum $\mathrm{L}$.) Ethanol extract n-hexan extract

$\begin{array}{lll}+ & + & + \\ + & + & + \\ + & + & + \\ + & - & + \\ - & - & - \\ + & + & + \\ + & + & + \\ - & + & - \\ - & + & - \\ + & - & + \\ + & + & +\end{array}$

aromatium L.) may be used as potential antibiotics and antioxidants.

\section{Conflict of interest}

The authors declared absence of conflict of interest.

References

Adedayo, O., Javadpour, S., Taylor, C., Anderson, W. A., \& Moo-Young, M. (2004). Decolourization and detoxification of methyl red by aerobic bacteria from a wastewater treatment plant. World Journal of

[Citation: Mahmood, H., Ali, Q., Hafeez, M.M., Malik, A. (2021). Antioxidant activity of Syzygium aromatium and Cinnamomum verum seed extracts. Biol. Clin. Sci. Res. J., 2021: 63. doi: https://doi.org/10.54112/bcsrj.v2021i1.63] 
Microbiology and Biotechnology, 20(6), 545550.

Anwar, F., Ali, M., Hussain, A. I., \& Shahid, M. (2009). Antioxidant and antimicrobial activities of essential oil and extracts of fennel (Foeniculum vulgare Mill.) seeds from Pakistan. Flavour and Fragrance Journal, 24(4), 170-176.

Chesson, A., \& Forsberg, C. W. (1997). Polysaccharide degradation by rumen microorganisms. In The rumen microbial ecosystem (pp. 329-381). Springer, Dordrecht.

Chesson, A., Stewart, C. S., \& Wallace, R. J. (1982). Influence of plant phenolic acids on growth and cellulolytic activity of rumen bacteria. Applied and Environmental Microbiology, 44(3), 597-603.

Diao, W. R., Hu, Q. P., Zhang, H., \& Xu, J. G. (2014). Chemical composition, antibacterial activity and mechanism of action of essential oil from seeds of fennel (Foeniculum vulgare Mill.). Food Control, 35(1), 109-116.

Dickinson, J. M., Smith, G. R., Randel, R. D., \& Pemberton, I. J. (1988). In vitro metabolism of formononetin and biochanin $\mathrm{A}$ in bovine rumen fluid. Journal of Animal Science, 66(8), 1969-1973.

Dua, A., Garg, G. and Mahajan, R. (2013). Polyphenols, flavonoids and antimicrobial properties of methanolic extract of fennel (Foeniculum vulgare Miller). European Journal of Experimental Biology. 3(4):203208.

Heng, L., Vincken, J. P., van Koningsveld, G., Legger, A., Gruppen, H., van Boekel, T., ... \& Voragen, F. (2006). Bitterness of saponins and their content in dry peas. Journal of the Science of Food and Agriculture, 86(8), 12251231.

Kaithwas, G., Mukerjee, A., Kumar, P., \& Majumdar, D. K. (2011). Linum usitatissimum (linseed/flaxseed) fixed oil: antimicrobial activity and efficacy in bovine mastitis. Inflammopharmacology, 19(1), 4552.

Lee, M. R., Winters, A. L., Scollan, N. D., Dewhurst, R. J., Theodorou, M. K., \& Minchin, F. R. (2004). Plant-mediated lipolysis and proteolysis in red clover with different polyphenol oxidase activities. Journal of the Science of Food and Agriculture, 84(13), 1639-1645.

Lo Cantore, P., Iacobellis, N. S., De Marco, A., Capasso, F., \& Senatore, F. (2004). Antibacterial activity of Coriandrum sativum
L. and Foeniculum vulgare Miller var. vulgare (Miller) essential oils. Journal of Agricultural and Food Chemistry, 52(26), 7862-7866.

Matan, N., Rimkeeree, H., Mawson, A. J., Chompreeda, P., Haruthaithanasan, V., \& Parker, M. (2006). Antimicrobial activity of cinnamon and clove oils under modified atmosphere conditions. International Journal of Food Microbiology, 107(2), 180-185.

Roby, M. H. H., Sarhan, M. A., Selim, K. A. H., \& Khalel, K. I. (2013). Antioxidant and antimicrobial activities of essential oil and extracts of fennel (Foeniculum vulgare L.) and chamomile (Matricaria chamomilla L.). Industrial Crops and Products, 44, 437445.

Singh, S., and Majumdar, D.K. (1999) Effect of Ocimum sanctum fixed oil on vascular permeability and leukocytes migration. Indian Journal of Experimental Biology, 37:11361138.

Singh, S., Malhotra, M. and Majumdar, D.K.. (2005) Antibacterial activity of Ocimum sanctum $\mathrm{L}$ fixed oil. Indian Journal of Experimental Biology 43:835-837.

Stewart, C.S., Flint, H.J. and Bryant, M.P. (1997). The rumen bacteria. InThe rumen microbial ecosystem. pp. 10-72. Springer, Dordrecht.

Sullivan, M.L. (2009) A novel red clover hydroxycinnamoyl transferase has enzymatic activities consistent with a role in phaselic acid biosynthesis. Plant Physiology, 150: $1866-1879$.

Zhang, Y., Liu, X., Wang, Y., Jiang, P., \& Quek, S. (2016). Antibacterial activity and mechanism of cinnamon essential oil against Escherichia coli and Staphylococcus aureus. Food Control, 59, 282-289.

\footnotetext{
(c) (1) 8

Open Access This article is licensed under a Creative Commons Attribution 4.0 International License, which permits use, sharing, adaptation, distribution and reproduction in any medium or format, as long as you give appropriate credit to the original author(s) and the source, provide a link to the Creative Commons licence, and indicate if changes were made. The images or other third party material in this article are included in the article's Creative Commons licence, unless indicated otherwise in a credit line to the material. If material is not included in the article's Creative Commons licence and your intended use is not permitted by statutory regulation or exceeds the permitted use, you will need to obtain permission directly from the copyright holder. To view a copy of this licence, visit http://creativecommons.org/licen ses/by/4.0/. (C) The Author(s) 2021
} 